\title{
ДОХОДИ ТА ВИТРАТИ НАСЕЛЕННЯ: АНАЛІТИЧНО-СТАТИСТИЧНИЙ АСПЕКТ
}

\section{INCOME AND EXPENDITURE OF POPULATION: ANALYTICAL AND STATISTICAL ASPECT}

\author{
Назарова Олександра Юріївна \\ кандидат економічних наук, доцент, \\ Харківський національний університет імені В.Н. Каразіна \\ ORCID: https://orcid.org/0000-0002-3014-1256 \\ Чуприна Олена Анатоліївна \\ кандидат економічних наук, доцент, \\ Харківський національний університет імені В.Н. Каразіна \\ ORCID: https://orcid.org/0000-0002-0548-0715 \\ Чатченко Тетяна Вікторівна \\ кандидат економічних наук, доцент, \\ Харківський національний університет імені В.Н. Каразіна \\ ORCID: https://orcid.org/0000-0002-5256-9157
}

\author{
Nazarova Oleksandra, Chuprina Olena, Chatchenko Tetiana \\ V.N. Karazin Kharkiv National University
}

\begin{abstract}
У даній статті здійснено аналітично-статистичне дослідження, щодо доходів та витрат населення, а також показників рівня якості життя в Україні та світі за 2019 р. Особливу увагу приділено статистичному аналізу розподілу доходу чи багатства в межах країни (регіону) за допомогою коесріцієнта Джині, а також розглянуто методику всіх способів щодо його розрахунків. Зазначено, що даний індекс $є$ інструментом для аналізу розподілу доходу чи багатства, а крива Лоренца широко використовується для їхнього наочного представлення (графрічний метод). Здійснено розрахунки індексу Джині, які підтвердили, що всі способи дають однаковий результат, що є достатньо важливим. Авторами також розглядається рейтинг коесіцієнту Джині по країнах світу у 2019 р. за даними Євростату. Важливо, що для України даний коефріцієнт рейтингу зійшовся з розрахованим - 0,3316 (33,16\%).
\end{abstract}

Ключові слова: аналітично-статистичне дослідження, доходи та витрати населення, коефріцієнт Джині, крива Лоренца, аналіз показників рівня життя.

В данной статье осуществлено аналитически-статистическое исследование, по доходам и расходам населения, а также показателей качества жизни в Украине и мире за 2019 г.. Особое внимание уделено статистическому анализу распределения дохода или богатства внутри страны или региона с помощью коэфффициента Джини, а также рассмотрена методика всех способов по его расчетам. Указано, что данный индекс является инструментом для анализа распределения дохода или богатства, а кривая Лоренца широко используется для их наглядного представления (графический метод). Осуществлены расчеты индекса Джини, которые подтвердили, что все способы дают одинаковый результат, что является достаточно важным. Авторами также рассматривается рейтинг коэффрициента Джини по странам мира в 2019 г. по данным Евростата. Важно, что для Украины данный коэффрициент рейтинга сошелся с рассчитанным - 0,3316 (33,16\%).

Ключевые слова: аналитическо-статистическое исследование, доходы и расходы населения, коэсфрициент Джини, кривая Лоренца, анализ показателей уровня жизни.

Data on incomes characterize the economic situation in a country, i.e. they can assess a number of economic and social problems, such as: identification of households at risk of economic crisis; distribution of total income in society; analysis and possibility of political laws influence. Aggregate income includes the total amount of income that a household receives from any source and in cash or in natural form. This article is devoted to analytical and statistical research on income and expenditure, as well as indicators of quality of life in Ukraine and the world in 2019. to Statistical analysis of income or wealth distribution within a country or region is paid particular attention. 
The Gini coefficient is used. The method of three ways by which the calculations are performed is considered. The index is noted to be a tool for analyzing the distribution of income or wealth, and the Lorentz curve is widely used for their visual representation (graphical method). Ginny index calculations confirmed that all the methods give the same result, which is quite important. The authors also consider the rating of the Gini coefficient in world countries for 2019 according to Eurostat, with Bulgaria having the highest figure at 41\%. It is important that for Ukraine this rating coefficient coincided with the calculated one $-0.3316(33.16 \%)$. Due to the fact that this index can range from 0 to 1 (the closer to 0 , the more evenly incomes are distributed, and 1 means all incomes belong to one household or group of the population). In this case, the Gini coefficient demonstrates that the distribution of income among the population of Ukraine is normal. Thanks to the use of the Gini coefficient, an analysis of the population and the impact on the economic situation in Ukraine was conducted. The study showed that the statistics of income and expenditure of the population is an important factor influencing the economic level of a country. Income inequality is inherent in many countries, not just Ukraine, because all important elements of development are closely linked. Undoubtedly, change, or rather increasing inequality, worsens the economic growth. Global inequality is a problem that needs to be addressed for years and constantly monitored for change.

Keywords: analytical and statistical research, incomes and expenditures of the population, Gini coefficient, Lorentz curve, analysis of living standards.

Постановка проблеми. Доходи та витрати населення завжди займають важливе місце у житті населення та країни в цілому. Підвищення доходів та зменшення витрат домогосподарств $€$ одною із найважливіших економічних проблем, на які звертає увагу уряд держави. Оскільки безпосередньо від даних показників залежить соціально-економічний стан країни та розвиток суспільства. 3і збільшенням доходів підвищуються якість життя та зростає споживання життєвих благ. Рівень життя характеризує темпи розвитку економіки, в Україні дана проблема особливо гостра. Як свідчать офріційні дані, доходи більшості населення в наш час не задовольняють достатній рівень життя.

Наявність нерівності в розподілі доходів, призводить до утворення споживчих структур, які розрізняються та діляться на соціальні групи населення з різним рівнем доходу. що призводить до розшарування населення та зміни в соціальному та трудовому розвитку країни. Коесріцієнт Джині демонструє нерівність, яка має зменшуватися, що в свою чергу, дасть можливість країні розвиватись більш стабільно та ефективно.

Аналіз останніх досліджень і публікацій. Окремі аспекти цієї проблеми розкрили у своїх роботах вітчизняні вчені, зокрема, В. Базилевич [1], С. Гончаров [2], Т. Кізима [3], Е. Лібанова [4], та ін.

У світі існують рейтинги та аналіз коефріцієнту Джині й показників рівня якості життя, які відображуються у звітах таких міжнародних організацій, як Євростат, Світовий банк та ін.

Виділення невирішених раніше частин загальної проблеми. Зазначимо, що в працях, які були розглянуті, приділено увагу переважно методологічним підходам щодо вивчення доходів та витрат населення. Вод- ночас $€$ необхідність в більш докладному аналітично-статистичному дослідженні стосовно якості рівня життя населення, а також необхідне подальше вивчення та розроблення напрямів для покращання ситуації в країні.

Формулювання цілей статті (постановка завдання). Важливість даної статті полягає у дослідженні розподілу доходів населення, що відображується на розвитку трудових ресурсів країни.

Виклад основного матеріалу дослідження. Важним інструментом для аналізу розподілу доходу чи багатства в межах країни чи регіону $є$ коефріцієнт Джині, але його не слід помилково приймати за абсолютне вимірювання доходу чи багатства. Країна 3 високим доходом та країна з низьким рівнем доходу можуть мати однаковий коесріцієнт Джині, якщо доходи розподіляються однаково всередині кожної країни.

Такий самий аналіз можна застосувати до розподілу багатства («коефріцієнт Джині багатства»), але оскільки багатство важче виміряти, ніж дохід, коефріцієнти Джині зазвичай належатиме до доходу й виглядають просто як «коефріцієнт Джині» або «індекс Джині», не вказуючи, що вони стосуються доходу. Коефріцієнти багатства Джині, як правило, набагато вищі, ніж коефріцієнти доходу.

Коефріцієнт Джині був розроблений італійським статистиком Коррадо Джині й опублікований у 1912 році, як узагальнений показник нерівності доходів у суспільстві, який пов'язаний із концентрацією багатства та запропонований раніше Максом Лоренцом. 3 того часу, як ці показники були введені, вони застосовуються до інших тем, окрім доходів та багатства, але переважно в рамках економіки.

Коефріцієнт Джині іноді критикують як надто чутливий до відносних змін. Ця чутливість 
виникає через те, що виведення коефріцієнта Джині показує рейтинг населення, і рейтинг, швидше за все, зміниться в найщільнішій частині розподілу доходу, яка, ймовірно, буде приблизно в середині.

Індекс концентрації доходів потрібен для вимірювання відхилення саме срактичного розподілу доходів за групами населення від їх рівномірного розподілу.

Даний індекс (коесріцієнт) можна розрахувати декількома способами.

1 спосіб:

$$
K_{j}=1-2 \times \sum x_{i} y(\text { cum })_{i}+\sum x_{i} y_{i},
$$

де $x_{i}$ - частка населення;

$y_{i}$ - частка доходів;

y(cum $)_{i}$ - кумулятивна частка доходу.

2 спосіб:

$K_{j}=\sum x(\text { cum })_{i} y(\text { cum })_{i+1}-\sum x(\text { cum })_{i+1} y(\text { cum })_{i}$,

де $x(\text { cum })_{i}$ - кумулятивна частка населення;

$y(\text { cum })_{i}$ - кумулятивна частка доходів.

Третій метод більш наочний, він вираховується за допомогою кривої Лоренца й визначається відношенням площі орігури (яку було утворено кривою Лоренца) та лінією рівномірного розподілу до площі трикутника який знаходиться нижче лінії рівномірного розподілу.

Крива Лоренца (ії також називають кривою відносної концентрації) широко використовується для представлення та аналізу розподілу розміру доходу (або багатства). Вона пов'язує частку сукупного доходу (багатства), заробленої різними групами населення, з часткою населення, яка отримує цей дохід. Коли одиниці розміщуються за збільшенням їх доходу Крива Лоренца показує сукупну частку доходу від різних верств населення.

Розрахуємо коесріцієнт Джині, як один з основних показників концентрації багатства населення. При розрахунку візьмемо дані за п'ятьма інтервалами, які представлені у табл. 1.

Порахуємо кумулятивний дохід (дохід однієї та всіх попередніх до неї груп) та переведемо всю таблицю в долі, табл. 2.

1-ий спосіб:

$K_{\text {дж }}=1-2 \times 0,2 \times\left(\sum 0,068+0,146+0,329+0,628+1\right)+$ $+0,2=1-2 \times 0,2 \times 2,171+0,2=0,3316$

2-ий спосіб:

$$
K_{\text {дж }}=1,3376-1,006=0,3316
$$

На рис. 1 представлено метод розрахунку коесріцієнту Джині, використовуючи $x(\text { cum })_{i}$ та $y(\text { cum })_{i}$.

Індекс Джині - це відношення площі до ідеального трикутника, площа ідеального трикутника дорівнює 0,5.

$$
K_{\partial ж}=0,1658 / 0,5=0,3316
$$

Всі вище розраховані способи дали однаковий результат, коесріцієнт Джині дорівнює 0,3316 (33,16\%). У зв'язку з тим, що даний показник може коливатись від 0 до 1, то чим

\section{Вихідні дані розподілу населення за об'ємом грошових доходів населення}

Таблиця 1 в Україні за липень 2020 року, \%

\begin{tabular}{|c|c|}
\hline 20\% групи населення & $\begin{array}{c}\text { Об'єм грошових доходів } \\
\text { населення у \% до суми }\end{array}$ \\
\hline Перша (найменші доходи) & 6,8 \\
\hline Друга & 7,8 \\
\hline Третя & 18,3 \\
\hline Четверта & 29,9 \\
\hline П'ята (найбільші доходи) & 37,2 \\
\hline
\end{tabular}

Джерело: побудовано авторами за даними [5]

Таблиця 2

Розраховані дані з розподілу населення за об'ємом грошових доходів населення для подальших розрахунків

\begin{tabular}{|c|c|c|}
\hline Відсоток населення & $\begin{array}{c}\text { Частка доходу } \\
\boldsymbol{y}_{\boldsymbol{i}}\end{array}$ & $\begin{array}{c}\text { Кумулятивна частка доходу } \\
\boldsymbol{y}(\mathbf{c u m})_{\boldsymbol{i}}\end{array}$ \\
\hline 0,2 & 0,068 & 0,068 \\
\hline 0,2 & 0,078 & 0,146 \\
\hline 0,2 & 0,183 & 0,329 \\
\hline 0,2 & 0,299 & 0,628 \\
\hline 0,2 & 0,372 & 1 \\
\hline
\end{tabular}

Джерело: побудовано авторами за даними [5] 


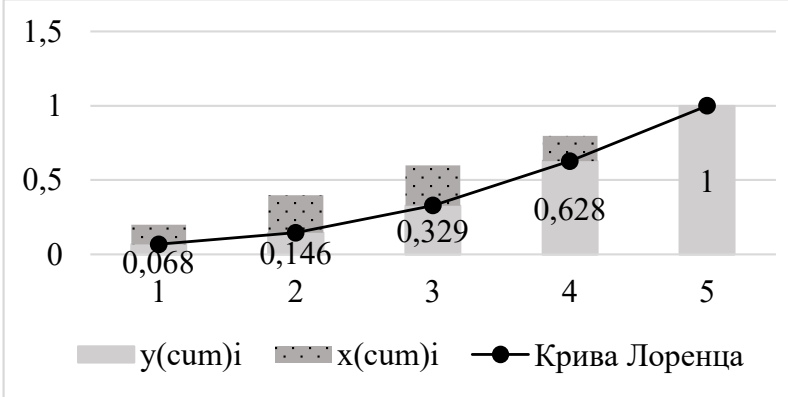

Рис. 1. Крива Лоренца за розрахованими даними

Джерело: побудовано авторами за даними [5]

ближче до 0, тим доходи населення розподілені більш рівномірно. Звичайно для України даний показник $є$ доволі позитивним, але для населення він не відіграє важливої ролі, оскільки бідні залишаються бідними, а багатіші тільки багатішають.

У зв'язку з тим, що індекс Джині представляється графрічно через криву Лоренца, яка показує розподіл доходів (або багатства), представимо даний розв'язок саме на грасріку, який $€$ більш наочним (рис. 2). Коесріцієнт Джині дорівнює площі під лінією повної рівності за вирахуванням площі під кривою Лоренца, розділеної на площу під лінією повної рівності. Іншими словами, це вдвічі більше площі між кривою Лоренца і лінією повної рівності.

Зростання інтересу до аналізу взаємозв'язків між розподілом доходів та економічним зростанням нещодавно стимулював нові теоретичні та емпіричні дослідження. Такі показники, як коефріцієнт чисельності населення для індексу бідності або широко

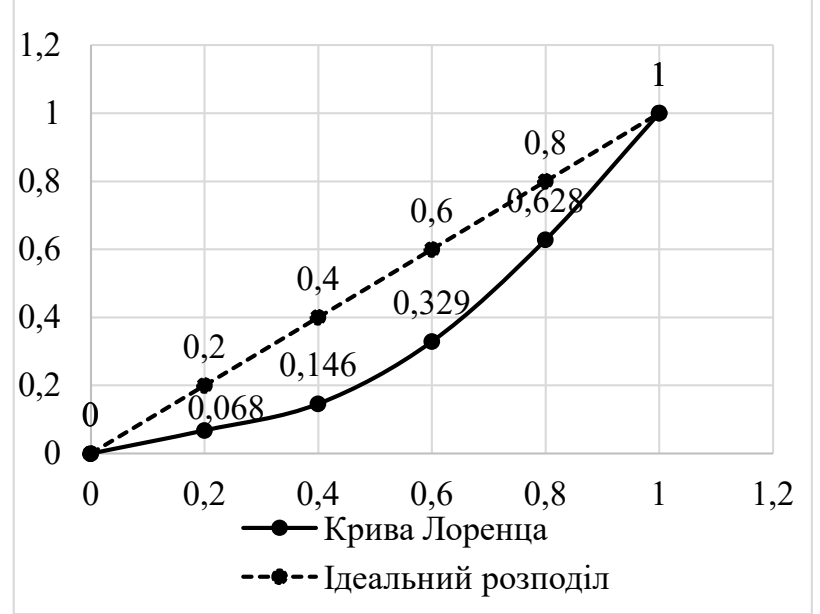

Рис. 2. Графічне зображення індексу Джині за розрахованими даними

Джерело: побудовано авторами за розрахованими даними

використовуваний коесріцієнт Джині, є агрегованими показниками, що описують загальний ступінь нерівності без глибшого розуміння розподілу доходів серед домогосподарств.

Показники коефіцієнту Джині за 2019 рік по деякім країнам світу представлено на рис. 3.

Відмітимо те, що коефріцієнт для України сходиться з нашими розрахунками, які було проведено.

Найвищий показник був розрахований для Болгарії, протягом 5-ти років, коесріцієнт Джині стрімко зростає для даної країни. Болгарія $€$ однією 3 країн, де ризик бідності населення перевищує середній показник по ЄС. Дана країна вважається однією з найбільш корумпованих країн Євросоюзу. Найменший розрив серед бід-

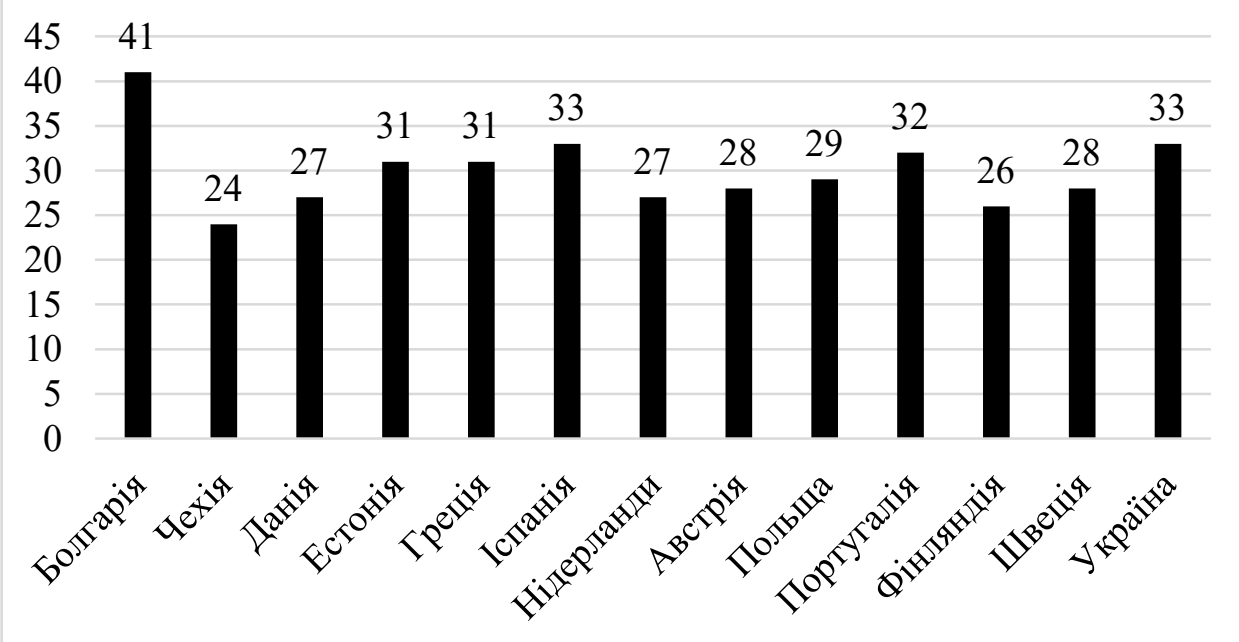

Рис. 3. Показники коефріцієнту Джині по країнам світу за 2019 рік Джерело: побудовано авторами за даними [6] 
них та багатих спостерігається в Чехії, де держава посідає перше місце серед країн 3 найнижчою бідністю серед населення від 18 до 25 років.

Не викликає сумнівів, що коефріцієнт Джині в еквівалентному наявному доході домогосподарств зростав більш-менш безперервно протягом останніх 25 років або близько, включаючи розвинуті країни та ті, що розвиваються.

Порівняння якості життя у всьому світі, займає важливе місце для кожного, хто планує переїзд або взагалі для загального розвитку. Еміграція - це дуже перспективно, але життя за кордоном не завжди приємне. Представлений рисунок 4 на основі даних Світового банку (порівнює якість повсякденного життя у 14 країнах). Індекс Джині складається з 7 напрямків, які відіграють важливу роль для оцінки відповідної країни.

Через свої позитивні громадянські права та загальну популярність США посідають не найкраще місце, але все ще мають досить високі показники, хоча висока вартість життя та відсутність безпеки в деяких районах $€$ негативними.

Загалом до розрахунку загального індексу Джині було включено 30 фракторів, які тут були розділені на 7 основних напрямків.

1. Економічна та політична стабільність. Світовий банк визначає цілу низку критеріїв політичної стабільності, де саме вона має найвищий пріоритет.

2. Правова система та громадянські права. Політична стабільність має не тільки позитивні наслідки, якщо вони базуються на диктаторських принципах. Прийняті закони мають не тільки добре звучати, але й виконуватися урядом. Крім того, до інших фракторів належать демократична участь населення та заходи боротьби з корупцією.

3. Медичні послуги. Найважливішим фрактором у секторі охорони здоров'я $€$ середня тривалість життя, яка показує інші фрактори, такі як регулярне та здорове харчування. Крім того, до даного показника враховували кількість лікарів та лікарняних ліжок щодо кількості мешканців.

4. Безпека. Навіть найкрасивіша країна не може нікого задовольнити, якщо їх власному життю загрожує небезпека. Найважливішу роль у цій галузі відіграє рівень вбивств у країні. Крім того, загальна кількість інцидентів, кількість вбитих, поранених та викрадених людей були включені до статистики тероризму.

5. Клімат. Для більшості емігрантів приємний клімат, безумовно, є найбільш очевидною причиною покинути дім. Оцінка клімату базується на різних дослідженнях, які передбачають максимальну добову температуру 25 градусів.

6. Витрати. Безумовно, найважливішим фрактором у цій галузі $€$ національна вартість життя, оскільки це найважливіший фрактор для життя у відповідній країні. Щодо цього фрактору було включено середньорічний дохід та сплачені податки, які також важливі. Таким чином, були також враховані максимальні ставки податку на дохід (прибуток).

7. Популярність. На відміну від інших показників, суб'єктивні оцінки мають відігравати певну роль. Тому загальний рівень міграції та кількість іноземних туристів оцінювались як показник популярності країни. Прохання про притулок, подані за останні п'ять років, також порівнювались із нижчим рейтингом.

Для того, щоб отримати характеристику для кожної країни, ключові показники для

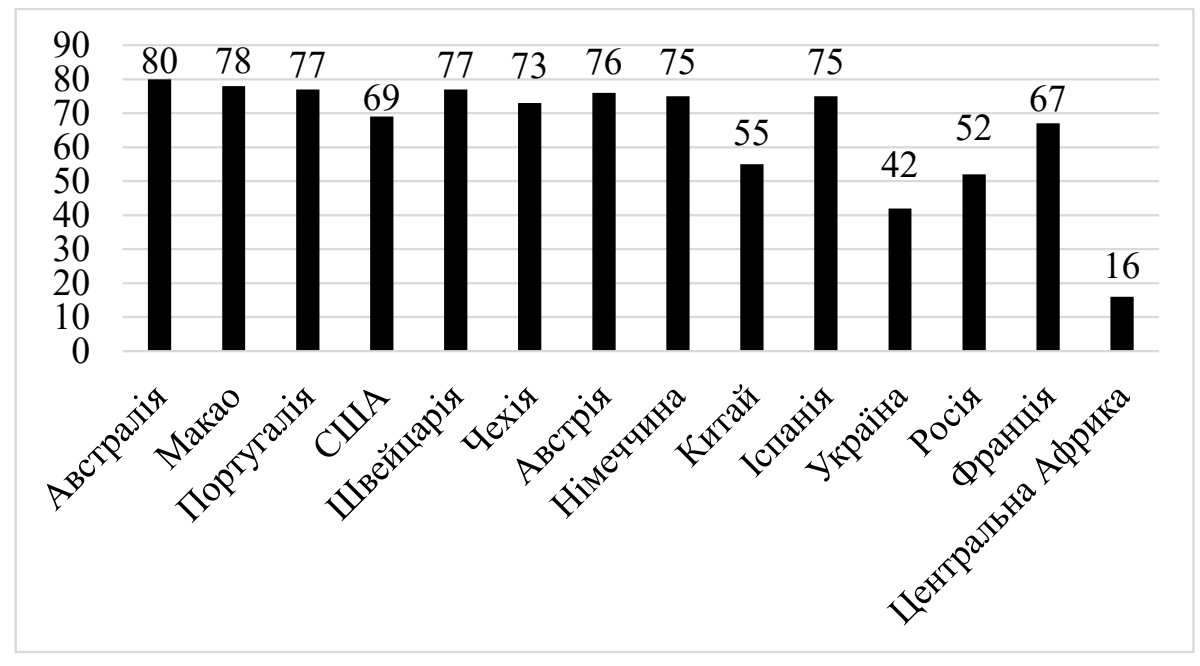

Рис. 4. Показники рівня якості життя по країнам світу за 2019 рік Джерело: побудовано авторами за даними [7] 
7 напрямків були включені до загального індексу Джині в різних пропорціях:

- стабільність - 14\%;

- громадянські права - 16\%;

- охорона здоров'я та медичні послуги - 16\%;

- безпека - 16\%;

- клімат - 14\%;

- витрати - 16\%;

- популярність - 8\%.

Враховуючи вище перераховані фрактори, виявлено, що найкращий рівень життя в Австралії, а найгірші умови життя в Центральній Афрриці. Україна посідає місце нижче середнього.
Висновки. Хоча коефіцієнт Джині корисний для аналізу економічної нерівності, він має деякі недоліки. Точність показника залежить від вірогідних даних про ВВП і доходи. Тіньова економіка і неформальна економічна діяльність присутні в кожній країні. Несрормальна економічна діяльність, як правило, становить більшу частину істинного економічного виробництва в країнах, що розвиваються і знаходиться в нижній частині розподілу доходів всередині країн. В обох випадках це означає, що індекс виміряних доходів Джині буде завищувати справжню нерівність доходів.

\section{СПИСОК ВИКОРИСТАНИХ ДЖЕРЕЛ:}

1. Базилевич В.Д., Базилевич К.С., Баластрик Л.О. Макроекономіка : підручник. Київ : Т-во «Знання», 2008. $64 \mathrm{c}$.

2. Гончарова С.Ю. Причини і тенденції зміни рівня доходів населення за регіонами України : навч. посіб. Херсон : ВД «Гельветика», 2015. 127 с.

3. Кізима Т.О. Доходи і витрати домогосподарств в системі показників рівня життя населення. Київ : Центр учбової літератури, 2013. 350 c.

4. Лібанова Е. Доходи населення і соціальна політика в умовах ринкових перетворень : підручник. Київ : Вища школа, 2003. 591 с.

5. Державна служба статистики України. URL: http://www.ukrstat.gov.ua (дата звернення: 01.09.2021).

6. Eurostat. URL: https://ec.europa.eu/eurostat/web/main/home (дата звернення: 15.09.2021).

7. WorldData.info. URL: https://www.worlddata.info/ (дата звернення: 11.09.2021).

8. Назарова О.Ю., Чуприна О.О. Аналіз розбіжностей в оцінках бідності та соціальної нерівності в Україні. Вісник Харківського Національного університету імені В.Н. Каразіна. 2014. № 87. С. 118-124.

9. Назарова О.Ю., Чуприна О.А., Чуприна О.О. Причини і наслідки соціальної нерівності в Україні та світі / Економіка сьогодення: актуальні питання та аспекти інноваційного розвитку : збірник наукових праць з актуальних проблем економічних наук. Дніпропетровськ : Наукова організація «Перспектива», 2015. С. 138-145.

\section{REFERENCES:}

1. Bazylevych V.D., Bazylevych K.S., Balastryk L.O. (2008) Makroekonomika [Macroeconomics]. Kyiv: T-vo «Znannja». (in Ukrainian)

2. Ghoncharova S.Ju. (2015) Prychyny i tendenciji zminy rivnja dokhodiv naselennja za reghionamy Ukrajiny [Reasons and trends in the level of income of the population by regions of Ukraine]. Kherson: VD «Helvetyka». (in Ukrainian)

3. Kizyma T.O. (2013) Dokhody i vytraty domoghospodarstv v systemi pokaznykiv rivnja zhyttja naselennja [Incomes and expenditures of households in the system of indicators of living standards]. Kyiv: Centr uchbovoji literatury. (in Ukrainian)

4. Libanova E. (2003) Dokhody naselennja i socialjna polityka v umovakh rynkovykh peretvorenj [Population incomes and social policy in the conditions of market transformations]. Kyiv: Vyshha shkola. (in Ukrainian)

5. State Statistics Service of Ukraine. Retrieved from: http://www.ukrstat.gov.ua/ (accessed 1 September 2021).

6. Eurostat. Retrieved from: https://ec.europa.eu/eurostat/web/main/home (accessed 15 September 2021).

7. WorldData.info. Retrieved from: https://www.worlddata.info/ (accessed 11 September 2021).

8. Nazarova O., Chupryna O. (2014) Analiz rozbizhnostei v otsinkakh bidnosti ta sotsialnoi nerivnosti v Ukraini. Visnyk Kharkivskoho Natsionalnoho universytetu imeni V.N. Karazina, 87, 118-124.

9. Nazarova O., Chupryna O., Chupryna O. (2015) Prychyny i naslidky sotsialnoi nerivnosti v Ukraini ta sviti I Ekonomika sohodennia: aktualni pytannia ta aspekty innovatsiinoho rozvytku: zbirnyk naukovykh prats z aktualnykh problem ekonomichnykh nauk. Dnipropetrovsk: Naukova orhanizatsiia «Perspektyva». 